\title{
Mahanaim; Altaic Letter from Tell Amarna; The Lachish Inscription; The Hebrews on the Tell Amarna Tablets; Baal Gad; Notes on the Quarterly Statement
}

\section{Major Conder}

To cite this article: Major Conder (1891) Mahanaim; Altaic Letter from Tell Amarna; The Lachish Inscription; The Hebrews on the Tell Amarna Tablets; Baal Gad; Notes on the Quarterly Statement, Palestine Exploration Quarterly, 23:3, 244-254, DOI: 10.1179/peq.1891.23.3.244

To link to this article: http://dx.doi.org/10.1179/peq.1891.23.3.244

曲 Published online: 20 Nov 2013.

Submit your article to this journal $₫$

Џll Article views: 4

Q View related articles ¿ 


\section{MAHANAIM.}

\section{By Major Conder, R.E.}

THIs city, one of the most important and interesting in Gilead, has usually been placed far north at Birket Mahneh, but, as I have attempted to show in "Heth and Moab," considerable confusion arises from such an identification (chap. vi, pp. 179-181, 1st edition) ; and I have proposed, therefore, to seek it much further south, somewhere east of Es Salt. After meeting Laban at Mizpeh (probably Saf), Jacob went on his way to Mahanaim (Gen. xxxii, 2). Thence he went to Penuel (v. 30), and afterwards rejoined his family, which had crossed the Jabbok (v. 22), and journeyed to Succoth (Gen. xxxiii, 17). If, then, Succoth be where Dr. Selah Merrill has shown it to be-at Tell Der'ala, north of the JabbokMahanaim should be sought somewhere south of the same, and near Penuel, which I have proposed to place at Neby Osh'a.

In Joshua xiii, 26-30, Mahanaim appears as the capital of a district, and as the east limit of Gad, as contrasted with "the border of Debir," or "limit of the ridge." It was a city of refuge (Josh. xxi, 38); the refuge of Ishbosheth beyond the "gorge" (Bithron), and evidently on the highlands (2 Sam. ii, 8, 12, 29). A man could thence be seen running on a plain, by David, when finding refuge there (2 Sam. xviii, 24-27; cf. 2 Sam. xix, 32 ; Kings ii. 8), and it was at some distance from the wood of Ephraim, which was beyond Jordan (2 Sam. xviii, 6 ; cf. xvii, 26). It was not in the same region with Ramoth Gilead (Reimûn), since it was the capital pof another province (1 Kings iv, 14 ; cf. 1 Chron. vi, 80). Finally, in Canticles (vi, 13), we read of the "company of two armies"

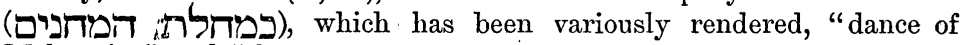
Mahanaim" and "dance of a double choir." The word is thus derived


geographic term for a circular basin or a "circuit," as, for instance, in the case of Abel Meholah (now 'A in Helweh).

The name Mahanaim (פְר) is also geographical, meaning "camp" or "camps" (Gesen) ; compare the Mahaneh Dan, or "plain of the camp of Dan," near Zorah and Eshtaol. In Arabic it becomes Mukhnah (di×o), as in the case of the well-known plain so called near Shechem, and the term would seem to indicate a plain.

On the newly issued map with ancient nomenclature will be found marked, east of Es Salt, the curious depressed plain of circular shape, which is called $E l$ Bukie'a, "the little vale," or, in the vulgar Bedu dialect, $E l B e j$ 'a. This is the position in which I have supposed Mahanaim to lie. A main road from Salt runs on the west side of the plain northwards, which I followed in 1882, going to Jerâsh. Here will be found marked the ruin Mukhnah (Lasio), which appears to me to 
preserve, somewhat distorted, the name of Mahanaim. The substitution of $m$ for $n$ is not a very strong objection, since in Syrian speech these two letters are often interchanged. The plain is several miles across, about 2,000 feet above sea level, with hills from 1,000 to 1,500 feet higher round it. The soil is sandy and fertile, the hills are of limestone. There is an important ancient ruin called $E l$ Basha, about a mile to the south with a fine clear spring. The ruins consist of a tower and round arched vaults, such as occur in many other ancient sites in Gilead, but which are probably of the second to fifth century A.D. Here, I think, we may therefore place the long lost Mahanaim, in a fertile district, near Penuel, south of the Jabbok, and east of the woods whence Salt (Saltus Hieraticus) took its name. The runners could be seen at some distance on the level road west of the plain, and the "circle" of Mahanaim would be the circle of the curious, basin in which it stands. The northern site should be abandoned, as not suiting the geographical requisites of the case.

\section{ALTAIC LETTER FROM TELL AMARNA.}

By Major Conder, R.E.

Arrong the 300 letters from Tell Amarna (1500-1450 B.c.) the longest of all is written to $\Lambda$ menophis III, by Dusratta, King of Mitani, or the region immediately east of the Euphrates, opposite the Hittite city of Carchemish. The first seven lines are in Assyrian, but, after this introduction, follow 505 lines in his own language. Dusratta wrote other letters in Assyrian which have been translated, and one of which refers to the same persons, Gilias and Manis, who are mentioned in this letter, of which nuany paragraphs are fairly well preserved, though others are too much broken to be read. The writing is syllabic, in an old cuneiform character, with a few determinatives.

Although the letter has not been translated, the meanings of a few words have been determined by Dr. Sayce and other scholars, and judging from these words, and from the terminations of verbs and nouns, it appears to me to be clear that the whole is written in a Mongol dialect, akin to the Akkadian and Medic. I am unable to find any resemblance to the Aryan language of the Vannic tribes, nor has Dr. Sayce pointed oul any, save a termination which also occurs in Akkadian. The known words are also not the same that stand for the same sense in Vannic. The vocabulary is very large, and great difficulties will no doubt arise in attempting to render the meaning, without the aid of bilinguals, but many of the words at once recall well-known Medic and Akkadian terms, and the same may be said of the commoner terminations.

The Assyrian introduction is much damaged, but the names of Amenophis and of Dusratta have already been recognised, with the 
usual invocation of peace and prosperity for the receiver of the tablet It appears roughly to have run as follows :-

"To Amenophis the third the [King] of Egypt, from Dusratta King [of Mitani]. I am at peace . . . may there be peace to . . . . . to thy ladies, to thy nobles, to thy horses, to thy land, and to all that is thine exceedingly."

The words which frequently recur, and of which the meaning is supposed to be known, are as follows :-

Atta, "Father." Akkadian, Adda; Medic, Ate; Turkish, LT, ata.

Amat, "grandfather ;" Am-at, "father's father." Compare the Tunguse ama, "father."

Sen, "brother." Compare the Turkic yin, a "younger brother," the $s$ being often softened to $y$. In Cantonese we have hing, "brother."

Dubsar, "scribe." Akkadian, dub, "tablet," and sar, "master."

Tsalam, "image" (used in Assyrian). Medic, zal zalmu, "image."

Enippi, "God." Medic and Susian, annap.

$T i$, "word." Turkic, tia, "say."

Pireta, "I have sent." Turkic, pir, " to go," pirat, " to despatch."

$U$, "I" (or Hu). Medic, $U, H u$, "I."

Nikhari, "written." Turkic, khar, " to engrave."

Talami, "interpreter." Turkic, talamis, "interpreter.'

Atinin, "these." Turkic, Atin, "that," "this."

$-n a$, plural ending. Mongol, -na; Akkadian, -ene.

$-s$, termination of the nominative, as in Hittite and Cassite.

Tissan Tissan, an adverb. Probably the Turkic tis, "quick," meaning "very quickly." Dr. Sayce renders it vehementer.

Tip, "to send." Medic, tip, "send."

To these words, which all point in one direction, I think we may add others which are equally suggestive, and of which a careful study of the text, as given by Dr. Winckler, shows the occurrence to be in accordance with the proposed interpretation. As instances may be cited-

Paza, "moreover." Turkic, paza, "again," "anew."

Khakhani, "Princes." Turkic, Khakhan, "Prince."

Khiarukka, "contracted." Turkic, Khiar, " to bind," "to wed."

Umun, "Lord." Akkadian, Umıın.

The name of the land of Egypt in this letter is written either Mazri or Mizri in different passages, and the Egyptians are called Mizrippi like the Medic, Muzzariyap, "Egyptians." The country whence the letters are despatched appears to be called KUR U, Minippi, "Land of the race of the Minni." This agrees with the position of Mitani, which is the name given to his country by Dusratta in the last part of the letter 
The Minni or Minyans were well known to the Assyrians as an Asia Minor people, and to the Egyptians as the Men or Menti, who are described in Egyptian records as dwelling in Assyria, "East of Syria." They were indeed the same race who, in the Hyksos period, had seized on Egypt itself, but had been driven uut some two centuries before the date of the letter under consideration. They seem to have been friendly with the Hittites, since in another of the Tell Amarna letters we read of a Hittite prince who fled to the land of Mitani, where he was captured. Dusratta was allied by marriage with Amenophis III, and his translated letters show that an alliance had also existed in the days of his grandfather or of his father, Suttarna, whose name suggests that he was a worshipper of Sut (or Set), the well-known Hittite god, The language of his letter also seems to indicate that he was of the same race with the Hittites and Akkadians. In modern Turkish this name Menua is applied to the Turks of Asia Minor.

The cases of the nouns, and the terminations of the verbs, also serve to show the Mongolic character of the language, as follows :-

\begin{tabular}{|c|c|c|c|c|c|}
\hline Nominative, ${ }^{1}$ & \multicolumn{5}{|c|}{$\begin{array}{l}-s \text { (as in Cassite, and in some instances in } \\
\text { Akkadian). }\end{array}$} \\
\hline Genitive, "of," & $-n$ & Akkadi &,$-n$ & Turkish, &,$-n$ \\
\hline Dative, "to," & $-a$, & . & & $\eta$ & $-e h$. \\
\hline Locative, "at," & $-d a$ & " & $-d a$ & & -deh. \\
\hline Accusative & $-i$ & $"$ & $-a$ & & $-i$ \\
\hline A blative, "from," & $-d a n$ & " & & & -den. \\
\hline Instrumental, " by," & $-l a$ & . & & & $-l e h,-l i$. \\
\hline Comitative, "with," & $-l a a n$ & & & & -ailan. \\
\hline Causative, "for," & $-i k k u$, & Medic, & $-\imath k h$ & & -ichun. \\
\hline
\end{tabular}

The verb would require much study to understand with certainty, but the following seem to be probable :-

Infinitive, a prefixed $n i$ occurs for the active, as in Akkadian : the passive appears to be -man.

Past tense, 1st singular, -ta (Medic, -ta), 3rd singular, -sà (Medic, -s).

Subjunctive, 3rd singular, -sena (Medic, -sne).

Imperative, 3rd singular, -s (Medic, $-s$ ).

The greater part of the syllabary is also the same used later in Medic.

1 Note.-The suffix ippi, added to the nouns, seems to form the definite case. It does not appear to be a plural. It is to be compared with what Lenormant calls the "absolute case" in Akkadian, which he compares with $-b$, the Lapp accusative, Samoyed - $p$, Mongol -ben. Castren derives it from the pronoun of third person, which is the Akkadian demonstrative $b$. In our letter, huwever, -ippi may also be the termination of the third person of verbs in a certain tense, as in Medic also, and apparently in Akkadian. This does not, 
In some passages the number of proper names renders the explanation somewhat more easy, but the number of words used is very great, and many of them are probably new, and not to be found in the small stock of inscriptions in cognate languages already understood. It is clear that the general subject relates to the sending of messengers, and to the interpretation of the letter; and the presents sent are also mentioned, while the last part seems to refer to the marriage of a lady. There are also passages in which, as Dr. Sayce has pointed out, the gods are invoked, including Ammon of Egypt, and the Akkadian god Ea, with Tessub, who is already known to have been a god compared by the Assyrians with Rimmon.

If, as seems to me certain from the considerations above noted, the language is one like Akkadian and Hittite (and indeed several of the words are the same used by the Hittite prince Tarkondara in writing to Amenophis III), it is clear that the syntax of a Turanian language must be strictly followed, the verb always standing at the end of the phrase, and not, as in Aryan speech, often first. None of the known words are Aryan, which it is almost unnecessary to say that they are not Semitic. The language, when fully understood, is likely to be of great value in the study of Hittite ; and it appears to me that some of the words, and nearly all the pronouns and terminations, are the same found on the Hittite monuments. This view as to the language being Hittite is, I understand, also held in Germany.

I venture on a tentative translation of some of the passages which are most perfect, though these may be subject to revision. The pious invocations are in the same tone found in passages in the Assyrian letters of Dusratta. Thus early in the letter (line 85-90) he prays to "Ammon and Simigin, to Ea, the King of Life," that they "may hasten very speedily .... assisting also my speech to be spoken in wisdom."

The letter appears to open with good wishes for the countries of the two kings of Egypt and of Mitani in the native language, and then refers to what had happened in the time of Suttarna.

Dusratta introduces his messengers, Manis and Gilias, in separate paragraphs, and proceeds to say : Amenophis, my Egyptian friend, knows that I live far off. I dwell in the city of lkhibin (or Idhibin), which is the city of the god Simigin, whom my father adored as a deity." The next passage (99) seems to mean, "let these whom I have sent (so far ?) be received, soon to approach the hall of thy palace." "Gilias . . . I have despatched who will add what does not appear in writing." "The god Simigin I have besought to prosper these things, prospering these . . . .

however, show, as some have argued, that there was no real distinction of verb and noun-which would be impossible in so fully developed a language. In English we do not consider that we have no distinction of these parts of speech, becauss we use $s$ as a termination for both, and also for the possessive. This suffix seems to be the Hittite $-P e$, represented by a long vase as distinguished from the round pot, $-a$. 
from the Land of the Minyan race, with the god Ammon, and with Ea the King of Life."

After various compliments a paragraph referring to "tablets" occurs, and apparently Dusratta asks for an answer. Dr. Sayce renders the word gipanu, "papyrus" (Akkadian gi, "reed," pa, "leaf," nu "letter," would be the explanation in such case I should suppose, i.e., "a letter on the pith of the reed"). Further on (col. 2, line 60), Dusratta appears to speak of the treasures sent with the messengers, "Invoking the gods to guard the presents with him," "an account being taken." "Gold" is here mentioned, "heaped up before you in abundance, bountifully given, let the gold be received as a gift." He proceeds : "By word of mouth, by writing, by interpretation, . . . replying soon . . . a answering my request quickly."

The writer then again (line 75) invokes the gods, Rimmon and Ammon, "may they cause my words to be received, through their wisdom, if I speak not clearly." This subject occupies a good many lines which follow, after which the writer returns to the question of Manis and the letter, which he apparently is to explain.

Another important passage, well preserved, is at the beginning of the back of the tablet. This refers to the "interpretation" or "translation" of the strange tongue. Dusratta then proceeds to speak of something connected with the letter which was to be done by Manis "with Gilias," and again invokes the assistance of the gods: this section ends up with the names of additional envoys, "also besides Manis, the envoy, to my brother, also besides Gilias, Artesupas and Asalinas are messengers. Asalinas, the interpreter of Gilias, my secretary" (this last clause is due to Dr. Sayce) "since he speaks this language together with my brother's language ... . in my embassy to my brother I have sent."

The next paragraph refers to a present of a gold throne (this has been pointed out already by Dr. Sayce) which was sent with the envoy. Dusratta then begins to reach the subject of his letter, which regards the affiance or marriage of a lady. The expression, nin es ie, clearly means "twenty-three months" (line 60), ie being the Akkadian ai, "month," "moon" (Turkish آي in some dialects, ye), and the gods are again invoked in this connection, after which the tablet is much injured. When it again becomes more perfect other deities are mentioned, including Sin, the Moon-god, and Ammon. Dusratta's own name occurs lower down (line 127) with the distinctive word umun, "Lord," preceding it, followed by the name of Amenophis III, of Egypt." In the next section a country called Pal musri is noticed. The passage seems to refer generally to difficulty in understanding, and to include the sentence, "my brother had ordered a clearly written reply." Then follows a clause possibly referring to the Hittites (line 16) "Âlû Khati-ma-an danga Esippias dan maan nuukka tilan âpi latakhkha Senippiûallan uru Kharanu sâussena," perhaps to be rendered, "the chieftain of my people of the land of the Hittites, all 
the people whom I conquered with my brother; he rules in the city of Harran." 1 As regards this passage it is to be noted that Egyptian records prove that Amenophis III, at some time during his long reign, had entered the country beyond the Euphrates, where he is said to have hunted lions ; and that Harran is usually supposed to have been in the same country, being the abode of Abraham on his way from Babylonia to Syria.

The letter continues to speak of the Land of the Minyans and of Embassies, and apparently of a reply to be sent. It then refers (line 35) to the time of his father and to tablets then written; also (line 53) to Artatas, the grandfather of Dusratta, "before my father," who again is called "my grandfather, my father's father" (as Dr. Sayce has pointed out). It continues (line 67) to refer to Gold in connection with his grandfather and father, and to a contract in the Land of the Minyans "contracted in the presence of the images" (of the gods). This contract seems to refer to a lady (line 90), "the woman my . . . affianced by my brother in the presence of the images," and soon after we read of "my god Sausbe in his presence in the city of Nineveh." The lady's name (line 103) was Tadukhepa, and the passage might perhaps be rendered "Tadukhepa to be taken in marriage, Dusratta of Mitani, ever a friend, desires of his friend Amenophis TII., the Egyptian. In the final paragraph there are two references to the "Princes ruling (or living) in the Land of the Minyan race," with a reference to " renewal of friendship and understanding," which no doubt would result from the marriage. Such appears to me to be the general subject of the longest and perhaps most interesting letter in the Tell Amama collection,

\section{THE LACHISH INSCRIPTION.}

By Major Conder, R.E.

Dr. Sayce's proposal (Quarterly Statement, April 1891, p. 158) to read Li Semak, depends mainly on his understanding of what he supposes to be the Samech. This appears to me to be quite untenable, because Phœnician letters consist of joined strokes, and not of strokes independent of each other, as in the case of the signs 4 그 which he renders as Samech. I subjoin the various early forms of the letter Samech.

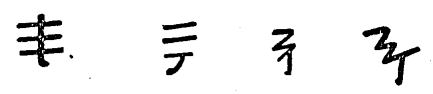

1 The Semitic letters from Tell Amarna speak of the Hittites very often. One mentions a Hittite prince fleeing to the land of Mitani. In others they are noticed as rebels seizing the city of Tunep (Tennib) which belonged to them also in 1360 B.c. 
In none of these is there any resemblance to the two letters of the Lachish text; which Dr. Sayce runs into one; whereas, taken separately, they are both well-known forms of the Heh and Nun. The suggestion of the scholar who does not append his name to his proposal is equally unsatisfactory. He neglects the Nun altogether. The Hei to which he would give the additional crooked stroke is one of the most constant letters of the Phœnician alphabet.$$
\exists \exists \exists \neg \exists \neg
$$

The early forms are as shown. None of them have more than four strokes. Both the proposed readings must therefore, I think, be rejected, as unsupported by, any extant evidence-so far as I am aware. Both scholars seem to me to be puzzled by the last letter but one, which they render MFim, though it is closely like a form of Vau known from the seals of 8 th cent. B.c.

\section{THE HEBREWS ON THE TELL AMARNA TABLETS.}

By Major Conder, R.E. .

Is the excellent translations of some of these invaluable letters by Father A. J. Delattre, S.J., it is noticed that the name of Canaan is spelt with the same sign which is used in the name of Gaza, to represent the Hebrew guttural y, not with the value $\mathrm{K} h$ or $\mathrm{G} h$, but with the value ' $a$. This agrees with what I have already published as to the 'A biri in these letters being the Hebrews. As the task of translation goes on it becomes apparent that the language and the system of characters used by the chiefs of Phœnicia and Canaan who were subject to the King of Egypt are neither of them purely Assyrian or Babylonian, but represent the Phœnician or Amorite language and writing of the age of Joshua.

\section{BAAL GAD. \\ By Major Conder, R.E.}

THIS is a somewhat important place, being the north limit of the Land of Israel according to the Book of Joshua (xi, 17 ; xiii, 5). Robinson placed it at Banias, but its position is defined in the two passages as being "in the valley of Lebanon, under "Mount Hermon," and the region inhabited by the Giblites is said to have extended thence to the entrance to Hamath. It seems to me, therefore, more probable that it should be 
sought on the north side of Hermon, since Banias could not be described as being in the valley of Lebanon, being in the Jordan Valley.

There is an important spring called 'Ain Jideideh, on the north of Hermon, on the road from Damascus to Beirut, and the plain here is called the Plain of Jideideh. This is close to the south end of the valley of Lebanon, and is at the foot of the north spurs of Hermon. The name comes from the root $A$, the same from which the Hebrew Gad is taken. It appears to me, therefore, that no position could be more suitable for Baal Gad, and that the name is preserved at a spring, as are the names of several ancient cities in Palestine, such as Chezib, for instance.

\section{NOTES ON THE QUARTERLY STATEMENT.}

\section{By Major Conder, R.E.}

Dr. Post's useful papers on the population sometimes apply rather to the Christian town population of Syria than to the peasantry of Palestine proper, or to the nomadic Arabs. Most of his statements I am able to confirm, as far as my six years' experience goes, but at times his experience is different to my own.

Pp. 110-111. The word fâs, pl. fits, was usually applied in my hearing not to a hatchet (an instrument I never remember seeing among the peasantry), but to the common hoe.

For the axe the Turkish word Balta I found to be commonly entployed.

P. 114. The form murej instead of nurej for the threshing sledge can hardly be considered a "corruption," because it is the older form, being the Hebrew moreg, and this is a proof of the archaic character of the peasant dialect.

P. 117. One custom in connection with the harvest, which may be regarded as superstitious or religious, Dr. Post does not mention, namely, leaving the corner of the field unreaped. Such a custom existed among the Celts in our own islands, and exists among the peasantry in India. In both cases the untilled part was sacred to the genius of the ground.

P. 121. The hyssop is often identified with the Origanum, as Dr. Post proposes, but Dr. Chaplin pointed out to me that the plant called Miriamîyeh is used to the present day much as hyssop was used, and grows on the walls of ruins as the hyssop is described to have grown in the Bible. This is the Satureia, a kind of plant resembling mint, and believed by scholars to be the $\tilde{v} \sigma \sigma \omega \pi$ os, or hyssop of the Greeks. The Za'ter, which is properly the thyme, never, as far as I know, grows on walls, and is therefore hardly to be identified with hyssop. It is very common on the soft chalky hills tinroughout Palestine. 
Many of the plants enumerated show their foreign derivation by their names, and probably came into Syria in post Christian times-such as the orange, potato, and perhaps the mulberry. Others roentioned in my recent paper on Greek words used by the Jews are also foreign, such as the lupine, pea, rice, tomato. Tobacco is in colloquial speech Dokhân, "smoke." The strong tobacco for the water-pipe is called Tumbak. The beech is unknown in Palestine itself. The Derdâr in the south is not a plane, but a thorny tree of the desert.

P. 126. As regards features, we observed that each village, as a rule, had its characteristic physiognomy, due to inter-marriage of the villagers, as I should suppose. In the north the type resembles that of the Assyrian monuments, in the south it approaches the Egyptian. The pure Arab type beyond Jordan is far more aquiline, and purely Semitic. The Christian population has probably much Greek blood in its veins, and often a good deal of Italian blood also. The peasantry may have Turanian blood of various stocks-from the Hittite down to the Turk. The Arab proper, in type and in speech, approaches nearer to the true Semitic type of Arabia. As regards height, I have met a good many very tall men in Palestine, especially in Philistia and beyond Jordan. The ugly ears of the Moslems-often bent down and always standing out-are accounted for by the great weight of the turban. The temper of Christian women is not, so far as I know, superior to that of the Moslem women. The recriminations of Christian women at the Well of Nazareth, for instance, are quite equal to those of their Moslem sisters. The beauties of Nazareth and Bethlehem are believed to have much Italian blood in their veins. Among the Druzes of Carmel I have seen a good many women quite as beautiful as any of the Christians, and others among the Adwân (who do not wear the veil) superior in type of aquiline beauty to any of the Christians. I have also personal experience of the very great muscular strength of many of the men. both among peasants and Arabs. Dr. Post's remark on this point (p. 127) seems rather to apply to the townsfolk. The keenness of eyesight and power of rapid observation, among the lower classes, is also worthy of notice.

I do not think that artists will agree with Dr. Post as to the want of taste among Syrians. The Oriental conception of colour is superior to that of most western peoples, as evinced both in costume and also in their fabrics.

The reasons for the position of towns and villages standing on heights appear to me to be: 1st, for security; 2nd, because the low ground near water is usually feverish. I doubt its being influenced by any particular love of scenery.

P. 134. Although the Syrians are very unpunctual, my experience always was that they were remarkably faithful to agreements, whether sealed or verbal. I have often entrusted muleteers with large sums of money, and never once.lost any so entrusted. The sanctity of a trust is one of the strongest sentiments of the peasantry. 
P. 137. The remarks as to the virtue of married women do not agree with what $I$ have heard from other residents. Many clandestine meetings are arranged, in remote fields or unfrequented spots, and the lepers are often the means of conveying such messages. The poisoning common armong women in Damascus is said to be mainly due to such irregularities. The morality of the herdsmen is also said to be notoriously bad.

The common word Yallah, used in all cases when "haste" is desired has, I believe, nothing to do with the name of God, or the invocation Ya-allah, "O God," though this is the common explanation. It is originally a Turkish word from the root yel, "to hasten," and is probably adopted from the Turks, who are the persons usually most accustomed to "hurry" their Semitic subjects.

P. 145. The assertion that "religion is universal" is not my experience. The Arabs have little religion, beyond a belief in: the presence of their ancestral spirits, and of demons in general. They very rarely are found to pray. The peasantry also are very ignorant of the tenets of Islam, and their beliefs belong to the old superstitions of earlier days. Of these superstitions Dr. Post has as yet told us nothing.

P. 187. I must apologise for supposing 프er Schumacher's tomb at Shefa 'Amr to be the same I explored. The similarity is remarkable.

P. 189. As regards the derivation of Millo, we may with advantage refer to the derivation given by Gesenius, who does regard the mim as servile. $\mathrm{He}$ derives it from the common Hebrew and Arabic root " to fill,"

\title{
THE GUTTER NOT NEAR THE FULLER'S FIELD.
}

\author{
By Rev. W. F. Birch.
}

In the astounding identification of " the conduit of the upper pool which is in the highway of the fuller's field" ( 2 Kings, xviii, 17), with the top of the Ophel shaft (i.e., the gutter) Mr. St. Clair finds good (!) evidence (p. 190) that "the shaft was outside the wall." As this would ruin my gutter, let me apply a little healthy criticism to his paper.

He says, "The upper pool is believed to be the Virgin's Fountain." Commonly, the worse the error the more it is believed; yet he omits to add by whom or on what evidence such a thing is believed. He and I agree that the Virgin's Fountain represents Gihon, but that Gihon was identical with the upper pool is (so far as I know) only a conjecture of Mr. St. Clair's, improbable' for at least two reasons. (A.) Names of places are not interchanged in the Bible without a note of explanation; and. 